\title{
How does resprouting response differ among three species of savanna trees and in relation to plant size?
}

\author{
Klécia Gili Massii* and Augusto César Franco ${ }^{1}$
}

Received: July 28, 2016

Accepted: December 5, 2016

\begin{abstract}
Cerrado tree species can survive fire by resprouting. Generally, large and less damaged plants produce new branches and leaves from stem buds (aerial), whereas small and highly injured individuals would resprout from the stem base or from underground organs (basal). We compared the three most common Cerrado woody plant species in a savanna area of the IBGE Ecological Reserve, Brasília, Brazil, aiming to verify if the resprouting strategy (aerial or basal) differed between species and if that was related to plant size. Guapira noxia had small-sized plants, a higher percentage of trunk charred and more individuals with basal resprouting, while Eriotheca pubescens had large-sized plants with a greater intensity of aerial resprouting, Basal resprouting was associated with disturbance severity for Dalbergia miscolobium, while plant size was associated with aerial resprouting for E. pubescens. None of variables explained the variation in resprouting of G. noxia. The results showed that the post-fire regeneration strategy varied according to the species, confirming other studies of post-fire resprouting.
\end{abstract}

Keywords: Cerrado, disturbance, fire, resprout, size, tree

\section{Introduction}

Fire has been occurring in the Brazilian savannas (Cerrado) for 10 million years (Simon et al. 2009; Simon \& Pennington 2012) and many Cerrado trees have survived fires because of traits such as thicker bark (Dantas \& Pausas 2013) which protects stems from high fire temperatures and prevent topkill, or deciduous leaves that are less vulnerable to fire or herbivory damage (Lucena et al. 2015). Among Cerrado woody plants, the main consequences of burning are partial to complete loss of aerial biomass and, in more severe cases, plant death (Coutinho 1982; Hoffmann 1998; Hoffmann \& Solbrig 2003; Hayashi \& Appezzato-da-Glória 2007; Hoffmann et al. 2009). In this phytogeographic domain, tree species may survive fires by resprouting (from basal, aerial and below-ground buds, Clarke et al. 2013) and resprouter species will have an advantage - compared to species growing from seeds - if burnings become more frequent (Ojeda et al. 2005).

Disturbance severity is perceived by a plant according to some characteristics, for instance the traits exemplified before, and also by plant size. The position of perennating buds is linked with bud protection (Raunkiaer 1934), and it may confer resilience to fire (Charles-Dominique et al. 2015) and facilitate escape from the fire-trap (repeated topkill and resprouting when fire is frequent: Grady \& Hoffmann 2012). Instead small trees most strongly experience the impact of fire because their entire aboveground biomass is within the flame zone (Lawes et al. 2011). In contrast, large individuals are less affected by fire and may avoid topkill (Raw \& Hay

\footnotetext{
${ }^{1}$ Departamento de Botânica, Universidade de Brasília, P.O. Box 04457, 70919-970, Brasília, DF, Brazil

* Corresponding author: kgmassi@gmail.com
} 
1985; Hoffmann 1998; Hoffmann \& Solbrig 2003; Sato et al. 2010). Thereby large and less damaged plants would produce new branches and leaves from primary stem buds (aerial resprout following Clarke et al. 2013), whereas small and highly injured individuals of resprouting species would develop new trees from the stem base or from underground organs (basal resprout, Clarke et al. 2013). However, if burning is frequent, even some large mature individuals may be subjected to topkill and be unable to regrow rapidly before subsequent fire (Hoffmann \& Solbrig 2003; Medeiros \& Miranda 2005).

Disturbance severity is perceived by a community according to the species composition and their traits. These traits (physiological, regeneration and resistance traits) arranged in distinct ways represent different strategies of plants to survive fires (Cianciaruso et al. 2012). In this research, two strategies (basal and aerial resprout: Clarke et al. 2013) are studied and we expected to observe speciesspecific responses in post-fire resprouting, between three common woody plant species of the Cerrado, related to the plant size.

Several studies have evaluated the resprouting of Cerrado tree species after fire and they have showed that resprouting ability is species-dependent (Raw \& Hay 1985; Salomão \& Leite 1993; Hoffmann \& Solbrig 2003; Medeiros \& Miranda 2005; Hoffmann et al. 2009; Silva et al. 2009; Vale \& Lopes 2010; Ribeiro et al. 2012). However, much of the existing research on regeneration following disturbances has focused on the role of other species rather than the woody species presented here (by the aforementioned authors), which are abundant species in most Cerrado physiognomies. Additionally, comparative studies relating post-fire responses to plant size are still scarce for these species. The incorporation of qualitative knowledge, such as the type of resprout (aerial or basal), could provide insights of the species ability to escape from the fire-trap and persist in areas experiencing higher frequency disturbances and inform post-fire management decisions. Thus, we aimed at verifying if the resprouting strategy (aerial or basal) differed between three woody Cerrado species and if that was related to plant size. We expected that large-sized individuals would resprout more from aerial buds, while small-sized ones would resprout basally and in higher frequency. Also, we aimed to observe if species changed the importance of strategies (basal and aerial resprouting) with time, as they recover after the disturbance.

\section{Materials and methods}

\section{Site description}

The study was performed at the IBGE (Instituto Brasileiro de Geografia e Estatística) Ecological Reserve, located $35 \mathrm{~km}$ south of Brasilia, in the Federal District of Brazil
(15 $5^{\circ} 55^{\prime}-15^{\circ} 58^{\prime} \mathrm{S}$ and $\left.47^{\circ} 52^{\prime}-47^{\circ} 55^{\prime} \mathrm{W}\right)$, at an elevation of $1100 \mathrm{~m}$. The Reserve encloses different Cerrado vegetation physiognomies, such as grasslands, savanna (cerrado sensu stricto), woodlands and gallery forests (Ribeiro 2011). The average annual rainfall recorded at IBGE meteorological station is $1461 \mathrm{~mm}$ (1980-2008), with a well-defined dry season from May to September and a mean annual temperature of $22.5^{\circ} \mathrm{C}$ (Paiva et al. 2015). Soils at the reserve are deep well-drained oxisols.

\section{Sampling design}

The research was carried out at the boundary between gallery (i.e. riparian) forest and savanna. Six transects were positioned perpendicularly to the boundary; each transect was $10 \mathrm{~m} \mathrm{x} 30 \mathrm{~m}$ and extended $30 \mathrm{~m}$ into the savanna. An accidental fire occurred in September 2011 and burned all individuals in savanna, which had only burned once in the previous 35 years due to a policy of fire suppression in the reserve.

The three most abundant species of the area were studied. Dalbergia miscolobium Benth. (Fabaceae) is a brevideciduous species distributed through the Brazilian savanna, which flowers in the end of the rainy season (March-April) and disperses its fruits at the end of dry season (Braz et al. 2009). Eriotheca pubescens (Mart. \& Zucc.) Schott \& Endl. (Malvaceae) is a deciduous, wind-dispersed, tree species, occurring in Cerrado areas of Central Brazil; it flowers from May to July and it fruits from October to November (Oliveira et al. 1992; Mendes-Rodrigues et al. 2005). Guapira noxia (Netto) Lundell (Nyctaginaceae) is a deciduous species, found in the cerrados and dry forests of Brazil, flowers from May to October and releases its fleshy fruits in November (Lorenzi 1992). In this study, 56 individuals were surveyed for E. pubescens, 30 for D. miscolobium and 16 for G. noxia. The sampling is not balanced in terms of species and it reflects the natural variation in population size showed by Fonseca \& Silva Júnior (2004), comparing Cerrado sites in Jardim Botânico de Brasília, a contiguous area of cerrado to the IBGE Ecological Reserve. For each individual we measured charred height - the vertical extent of outer bark blackening - and size, represented by tree height and stem diameter. We also quantified the number of basal resprouts (BR) and we estimated the proportion of new leaves in the canopy, as an indication of aerial resprouting (AR). We estimated new leaves based on a percentage of the living canopy, using a semiquantitative index of phenophase intensity ranging from 0 (absence) to 4 (76-100\% of the canopy occupied by new leaves), with a $25 \%$ interval between each presence class (Fournier 1974). The first and second surveys were performed 13 February 2012, at the end of the wet season because plants had the entire growing season to resprout, and 31 November 2012, more than one year after burning, respectively. We assessed one commonly used indicator of fire severity and potential tree injury: the proportion of 
tree charred height (PCH: Catry et al. 2013).

\section{Data analysis}

Non-parametric tests were performed because our data did not fit a normal distribution. Wilcoxon signed-rank test was performed to compare parameters between species and years. Relationships between post-fire responses and explanatory parameters (Tab. 1) collected at the tree level were evaluated by calculation of Spearman's correlation coefficient. Statistical analyses were performed using the $R$ version 3.2.1 (R-Development Core Team 2013).

\section{Results}

Mortality was low (two individuals in 102). Guapira noxia had small-sized plants, higher percentage of trunk charred and relatively more individuals with basal resprouts (38\% of the individuals resprouted from the base) than $D$. miscolobium and E. pubescens (Tab. 2). Eriotheca had largesized plants, and consequently more leaves before burning.
BRs was lower in G. noxia and ARs was higher in E. pubescens (Tab. 2).

None of the independent variables explained the variation in the response parameters of G. noxia (Tab. 3). For D. miscolobium, PCH was positively correlated to BRs $(\mathrm{p}=0.02$, Fig. 1A). For E. pubescens, diameter and height were negatively correlated to BRs $(\mathrm{p}=0.02$ and $\mathrm{p}=0.02$, respectively), while they were strongly positively correlated to ARs ( $p<0.001$, for diameter - Fig. 1B, and height); leaf crop before fire was associated with ARs ( $p=0.002)$; and PCH was related to BRs ( $\mathrm{p}=0.001)$ (Tab. 3).

Fourteen months after fire the number of basal resprouts (BRy) for the three studied species was not different from the five months post-fire (D. miscolobium: $\mathrm{p}=0.50$; E. pubescens: $\mathrm{p}=0.23$ and $G$. noxia: $\mathrm{p}=0.13)$. E. pubescens flushed vigorously after the first rains (ARs: about $75 \%$ of the canopy with new leaves), but one year after this measurement we registered less leaves in the canopy (ARy: $50 \%$ of the canopy had leaves, $\mathrm{p}=0.01$ ); the other two species apparently did not produce or loose leaves in this period, as AR did not change with time (D. miscolobium: $\mathrm{p}=0.25$ and $G$. noxia: $\mathrm{p}=0.15)$.

Table 1. Summary of the variables assessed for each tree.

\begin{tabular}{|c|c|c|}
\hline Variable [code] & Units & Type \\
\hline Tree regeneration status & 4 cat. $^{\mathrm{a}}$ & - \\
\hline Number of basal resprouts at the end of the first growing season after fire (BRs) & & $\mathrm{R}, \mathrm{E}$ \\
\hline Intensity of aerial resprouts at the end of the first growing season after fire (ARs) & 5 cat. $^{\text {b }}$ & $\mathrm{R}, \mathrm{E}$ \\
\hline Number of basal resprouts one year after fire (BRy) & & $\mathrm{R}$ \\
\hline Intensity of aerial resprouts one year after fire (ARy) & 5 cat. $^{\text {b }}$ & $\mathrm{R}$ \\
\hline Leaves before fire & 5 cat. $^{\text {b }}$ & E \\
\hline Diameter at soil height & $\mathrm{cm}$ & $\mathrm{E}$ \\
\hline Tree height & $\mathrm{m}$ & $\mathrm{E}$ \\
\hline Percentage of charred height (PCH) & $\%$ & E \\
\hline
\end{tabular}

In Leaves before fire and AR: five categories: 0=0 \%, 1=until $25 \%$, 2=until $50 \%, 3=$ until $75 \%$, $4=$ until $100 \%$ of the canopy occupied by leaves and branches. All data is given as median with first and third quartile. Values followed by the same letter do not differ amongst themselves following Wilcoxon signed-rank test.

Table 2. Plant Size, percentage of tree charred height ( $\mathrm{PCH}$ ), number of basal resprouts (BRs) and intensity of aerial resprouting in the growing season soon after fire (ARs) for each tree species.

\begin{tabular}{|l|c|c|c|}
\hline Species & D. miscolobium & E. pubescens & G.noxia \\
\hline Diameter $(\mathrm{cm})$ & $7(7 ; 10) \mathrm{a}$ & $13(11 ; 15) \mathrm{b}$ & $7(6 ; 8) \mathrm{a}$ \\
\hline Height $(\mathrm{m})$ & $4(4 ; 5) \mathrm{a}$ & $4(4 ; 5) \mathrm{a}$ & $3(3 ; 4) \mathrm{b}$ \\
\hline PCH $(\%)$ & $44(32 ; 75) \mathrm{a}$ & $69(40 ; 87) \mathrm{a}$ & $89(62 ; 100) \mathrm{b}$ \\
\hline Leaves before fire & $2(1 ; 2) \mathrm{a}$ & $3(3 ; 4) \mathrm{b}$ & $3(1 ; 3) \mathrm{a}$ \\
\hline BRs & $3(1 ; 6) \mathrm{a}$ & $3(1 ; 5) \mathrm{a}$ & $3(1 ; 4) \mathrm{b}$ \\
\hline ARs & $3(0 ; 3) \mathrm{a}$ & $4(3 ; 4) \mathrm{b}$ & $2(0 ; 3) \mathrm{a}$
\end{tabular}

In Leaves before fire and AR: five categories: $0=0 \%, 1=$ until $25 \%, 2=$ until $50 \%, 3=$ until $75 \%, 4=$ until $100 \%$ of the canopy occupied by leaves and branches. All data is given as median with first and third quartile. Values followed by the same letter do not differ amongst themselves following Wilcoxon signed-rank test. 

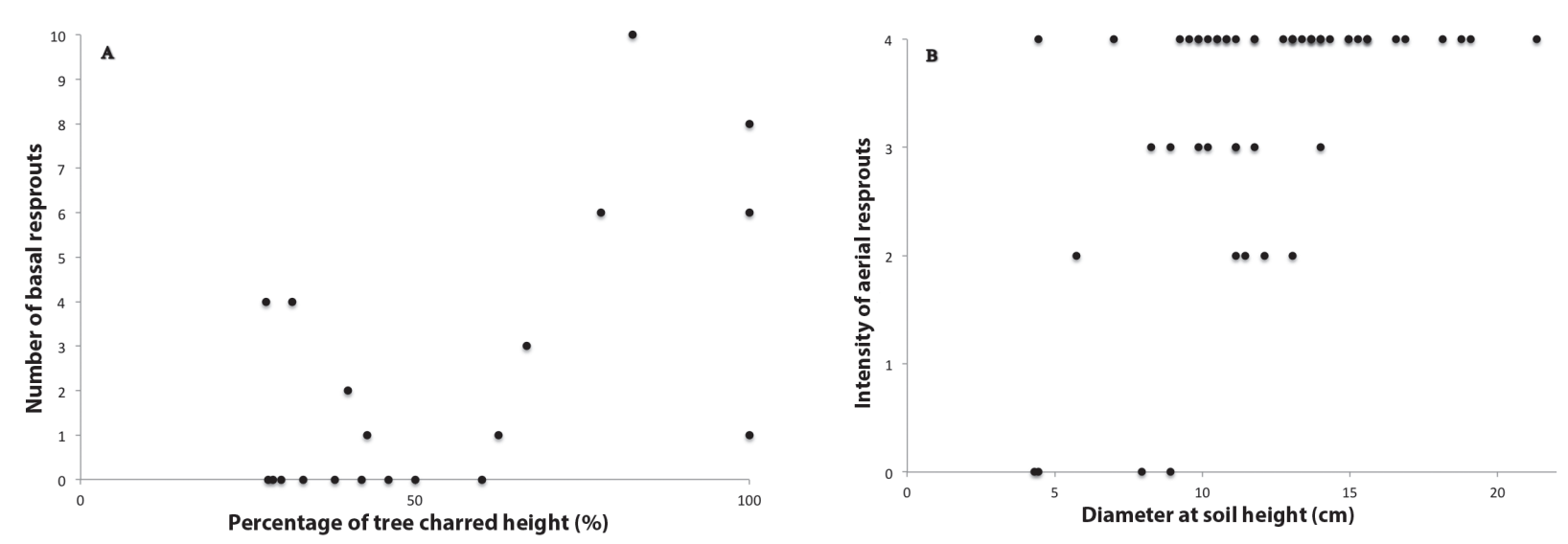

Figure 1. Relationships between the number of basal resprouts in the growing season soon after fire (BRs) and the percentage of tree charred height $(\mathrm{PCH})$ for Dalbergia miscolobium (A) and between the intensity of aerial resprouting in the growing season soon after fire (ARs) and plant diameter for Eriotheca pubescens (B).

Table 3. Ro-values of the Spearman correlation between some variables for each tree species individually. Values in bold are significant.

\begin{tabular}{|l|c|c|c|c|c|c|}
\hline & \multicolumn{2}{|c|}{ D.miscolobium } & \multicolumn{2}{c|}{ E. pubescens } & \multicolumn{3}{c|}{ G. noxia } \\
\cline { 2 - 8 } & BRs & ARs & BRs & ARs & BRs & ARs \\
\hline Height & 0.005 & 0.077 & $\mathbf{- 0 . 3 0 2}$ & $\mathbf{0 . 5 6 0}$ & -0.248 & 0.154 \\
\hline Diameter & -0.022 & 0.009 & $\mathbf{- 0 . 3 1 5}$ & $\mathbf{0 . 5 4 7}$ & -0.148 & 0.194 \\
\hline PCH & $\mathbf{0 . 5 1 2}$ & -0.407 & $\mathbf{0 . 4 2 1}$ & -0.151 & 0.326 & -0.399 \\
\hline Leaves before fire & -0.245 & 0.287 & -0.190 & $\mathbf{0 . 4 0 4}$ & -0.193 & 0.246 \\
\hline
\end{tabular}

$\mathrm{PCH}=$ Percentage of tree charred height, $\mathrm{BR}=$ number of basal resprouts and AR=intensity of aerial resprouts, s: soon after fire.

\section{Discussion}

Our results confirm that stem mortality (topkill) of Brazilian savanna species is more prevalent than death of an individual (Hoffmann \& Solbrig 2003). The vast majority of the studied individuals survived, persisting through resprouting, but we showed that the type (aerial or basal) and magnitude (in terms of numbers of resprouts) of the regeneration vary according to the species, plant size and damage severity.

Guapira noxia (that had $73 \%$ of its plants smaller than $7.5 \mathrm{~cm}$ for stem diameter and shorter in height) suffered more severe damage and more individuals resprouted basally. Although for this particular species tree charred height and the number of basal resprouts were not related, the strategy of resprouting from stem base or underground tissues is a typical response to higher damage level and/or smaller plant size (Belingham \& Sparrow 2000; Tredici 2001; Jancosky 2010; Vale \& Lopes 2010; Ribeiro et al. 2012). Dalbergia and Eriotheca that had larger size individuals flushed and resprouted mainly from stem buds (personal observations), confirming other cerrado fire studies (Ribeiro et al. 2012).

These different regeneration strategies may have longterm structural and compositional consequences according to variations in fire severity: under high-severity fires, the post-fire stature of Cerrado woody species would be reduced because of topkill and regeneration through basal resprouting; by contrast, low severity fires would cause less change due to aerial resprouting and high levels of survival. We believe Reserva Ecológica do IBGE experienced a medium severity fire because it has only burned once in the previous 35 years, the tree crowns were not scorched and consumed, but much of the dry phytomass concerning grasses and dry herbs were burnt (personal observations). Our results of aerial resprouting prevalent in Eriotheca and Dalbergia individuals and basal in Guapira ones can confirm the effects of this medium severity burning on abundant species of Cerrado and brought important insights about species-specific resprouting ability.

Guapira noxia had more individuals with basal resprout, but it also had lower resprout number per plant (one to four shoots). Other studies have shown an average of ten shoots for each Tapirira guianensis tree (Jancosky 2010) and some Eucalyptus species can produce up to 21 basal resprouts (Catry et al. 2013). For aerial resprouts some interesting differences appeared: individuals of Guapira and Dalbergia were not fully covered with new leaves and branches, and some had not flushed at all, after one entire post-burning growing season, surviving predominantly by basal resprouts, while Eriotheca intensively invested 
in foliage after fire. This pattern may indicate that buds of Eriotheca species are more effectively protected from fire, confirming the findings of Charles-Dominique et al. (2015) that species with the most bud protection have greater canopy resprouting. Additionally, the greater the stem diameter: i) the more the number of apical buds (Lau 2009) of Cerrado woody species and consequently the higher the number of leaves (Farnsworth \& Niklas 1995) and ii) relatively the higher the bark thickness providing stem insulation (Dantas \& Pausas 2013). Eriotheca pubescens had $82 \%$ of the individuals larger than $10 \mathrm{~cm}$ diameter, it may have had more apical buds and it had thicker bark (unpubl. res.) than the other two species.

Plant size (specifically diameter, height and, indirectly, leaf crop before fire) was related to the aerial resprouts only for Eriotheca (most of Guapira and Dalbergia plants were smaller than $7.5 \mathrm{~cm}$, and probably younger individuals). The influence of size on post-fire plant flushing for this species corroborates many other Cerrado studies (Medeiros \& Miranda 2005; Vale \& Lopes 2010; Ribeiro et al. 2012). Although the relation was significant for only one species, pre-fire size may be a crucial factor determining how buds are protected during a burning event (Hoffmann \& Solbrig 2003) - we again argue that Eriotheca buds seem more effectively protected than the other two species and how much nutrients a plant can acquire from root storage tissues and relocate to aerial growth (Kennard et al. 2002). Regarding basal resprouts, the higher the fire damage severity of Dalbergia and Eriotheca trunks, the more resprouts the species produced (Belingham \& Sparrow 2000; Catry et al. 2013). Aerial and basal resprouts of G. noxia and $D$. miscolobium did not associate with any plant-size parameter, indicating that for these two species, and maybe for more Cerrado species, other factors not evaluated here can influence the resprouting strategy (like bark thickness: Pausas 2015).

One year after fire, the three studied species had the same number of basal resprouts than in the post-fire growing season. Other authors have shown that resprout senescence of Cerrado species may start within nine months, or as late as fourteen months (Cardinot 1988). Kauffman (1991) reported that plant resprouts of forest trees have died as the forest canopy restored. In fact, the shading of shoots by recovering vegetation and competition between resprouts can lead to senescence and mortality (Kauffman 1991; Vila \& Terradas 1995), what we did not observe during the survey period.

The post-fire leaf crop of Dalbergia and Guapira did not change during the 13-month survey period. Typically fire incinerates or scorches old leaves, and plants produce new leaves just after the first rains (Vieira et al. 1996; Franco 1998). The three studied deciduous species (one is brevideciduous) commonly would have dropped their leaves in the dry season, but the high post-burning investment in canopy reconstruction may have postponed this phenological event for next year's dry season. Also, water supply to leaves can be greater after fire, which could prevent leaf senescence (Schafer et al. 2014). Only Eriotheca pubescens had less leaves 14 months after fire. The anemochoric-fruit dispersal of this species, at the end of the dry season (October-November), is favored by leaf shedding (Oliveira \& Moreira 1992) and less leaves in the canopy can be a strategy to maximize wind-dispersal.

Our results indicate that the resprouting patterns may vary in a burned community depending on the species. One could say that this species-specific response is actually a function of the species phenological state when the fire event takes place (Malanson \& Trabaud 1988). Dalbergia was changing leaves, Eriotheca was fruiting and launching seeds and Guapira was flowering when fire burnt the study area. The reproductive phase is a resource-demanding plant life history stage and may impose harsh recovery constraints especially for Eriotheca and Guapira. In addition, other morphological attributes may be responsible for the different post-fire resprouting behaviour of the three studied species. The reconstruction of the large-sized and thick leaves of Eriotheca and Guapira compared to the small and smooth leaflets of Dalbergia represent other dissimilar strategies between Cerrado species that can represent extra costs for resprouting.

In summary, the post-fire regeneration strategy (aerial and basal resprouting) varied according to the plant size and damage severity between Dalbergia, Eriotheca and Guapira species, suggesting that other Cerrado woody species may also have distinct post-fire resprouting responses. Nevertheless, similar results relating the level of trunk fire injury and basal resprouting would probably be obtained for other species, as we found for two tree species in this study. It has been argued that Cerrado woody species occurring together and under similar environmental conditions would have close-related phenotypic traits (Silva \& Batalha 2009). However, burning resistance strategies depend on historical fire regimes (especially fire frequency) that can lead to many different plant responses, as for example bud protection and bark thickness, not evaluated here and that still need to be better understood for Cerrado tree species. Knowing how trees respond to fire and what the factors are, such as the damage severity and plant size evaluated in this study, driving such responses is important for helping management decisions, particularly in Cerrado where fire is a recurrent disturbance.

\section{Acknowledgements}

We thank to CNPq (process number 140663/2012-6) and Capes (process number 17583/12-8) for funding, to the IBGE Ecological Reserve for permission to conduct research and to an anonymous reviewer for useful suggestions. 


\section{References}

Bellingham PJ, Sparrow AD. 2000. Resprouting as a life history strategy in woody plant communities. Oikos 89: 409-416.

Braz MSS, Souza VC, Andrade LA, Bruno RLA, Oliveira LSB, Silva JM. 2009. Caracterização morfológica de frutos, sementes e plântulas de jacarandá-da-bahia (Dalbergia nigra (Vell.) Fr. All.ex. Benth) Leguminosae-Papilionoideae. Revista Brasileira de Ciências Agrárias 4: 67-71.

Cardinot GK. 1998. Efeitos de diferentes regimes de queimas nos padrões de rebrotamento de Kielmeyera coriacea Mart. e Roupala montana Aubl., duas espécies típicas do cerrado. MSc Thesis, Universidade de Brasília, Brazil.

Catry FX, Moreira F, Tujeira R, Silva JS. 2013. Post-fire survival and regeneration of Eucalyptus globulus in forest plantations in Portugal. Forest Ecology and Management 310: 194-203.

Charles-Dominique T, Beckett H, Midgley GF, Bond WJ. 2015. Bud protection: a key trait for species sorting in a forest-savanna mosaic. New Phytologist 207: 1052-1060.

Cianciaruso MV, Silva IA, Batalha MA, Gaston KJ, Petchey OL. 2012. The influence of fire on phylogenetic and functional structure of woody savannas: Moving from species to individuals. Perspectives in Plant Ecology, Evolution and Systematics 14: 205-216

Clarke PJ, Lawes MJ, Midgley JJ, et al. 2013. Resprouting as a key functional trait: how buds, protection and resources drive persistence after fire. New Phytologist 197: 19-35.

Coutinho LM. 1982. Ecological effects of fire in Brazilian cerrado. In: Huntley BJ, Walker BH. (eds.) Ecology of tropical savannas. Berlin, Springer-Verlag. p. 273-291.

Dantas VL, Pausas JG. 2013.The lanky and the corky: fire-escape strategies in savanna woody species. Journal of Ecology 101: 1265-1272.

Farnsworth KD, Niklas KJ. 1995. Theories of Optimization, Form and Function in Branching Architecture in Plants. Functional Ecology 9: 355-363.

Fonseca MS, Silva Júnior MC. 2004. Fitossociologia e similaridade florística entre trechos de Cerrado sentido restrito em interflúvio e em vale no Jardim Botânico de Brasília, DF. Acta Botanica Brasilica 18: 19-29.

Fournier LA. 1974. Un método cuantitativo para la medición de características fenológicas en árboles. Turrialba 24: 422-423.

Franco AC 1998. Seasonal patterns of gas exchange, water relations and growth of Roupala montana, an evergreen savanna species. Plant Ecology 136: 69-76.

Grady JM, Hoffmann WA. 2012. Caught in a fire trap: Recurring fire creates stable size equilibria in woody resprouters. Ecology 93: 2052-2060.

Hayashi AH, Appezzato-da-Glória B. 2007. Anatomy of the underground system in Vernonia grandiflora Less. and V. brevifolia Less. (Asteraceae). Brazilian Archives of Biology and Technology 50: 979-988.

Hoffmann WA. 1998. Post-burn reproduction of woody plants in a neotropical savanna: the relative importance of sexual and vegetative reproduction. Journal of Applied Ecology 35: 422-433.

Hoffmann WA, Adasme R, Haridasan M, et al. 2009. Tree topkill, not mortality, governs the dynamics of alternate stable states at savannaforest boundaries under frequent fire in central Brazil. Ecology 90: 1326-1337.

Hoffmann WA, Solbrig OT. 2003. The role of topkill in the differential response of savanna woody plants to fire. Forest Ecology and Management 180: 273-286.

Jancosky HS. 2010. Efeito do fogo sobre a vegetação arbórea e herbácea em campo de murundus no Parque Estadual do Araguaia-MT. MSc Thesis, Universidade de Brasília, Brazil.

Kauffman JB. 1991. Survival by sprouting following fire in tropical forests of the eastern Amazon. Biotropica 23: 219-224.

Kennard DK, Gould K, Putz FE, Fredericksen TS, Morales F. 2002. Effects of disturbance intensity on regeneration mechanisms in a tropical dry forest. Forest Ecology and Management 162: 197-208.

Lau OL. 2009. Evolution of tree architecture in the Brazilian Cerrado. MSc Thesis, North Carolina State University, USA.
Lawes MJ, Clarke PJ. 2011. Ecology of plant resprouting: populations to community. Plant Ecology 212: 1937-1943.

Lorenzi H. 1992. Árvores Brasileiras: manual de identificação e cultivo de plantas arbóreas nativas do Brasil. Vol. 4. Nova Odessa, Editora Plantarum.

Lucena IC, Leite MB, Matos DMS. 2015. A deciduidade foliar indica a vulnerabilidade de espécies lenhosas ao fogo. Revista Árvore 39: 59-68.

Malanson GP, Trabaud L. 1988. Vigour of post-fire resprouting by Quercus coccifera L. Journal of Ecology 76: 351-365.

Medeiros MB, Miranda HS. 2005. Mortalidade pós-fogo em espécies lenhosas de campo sujo submetido a três queimadas prescritas anuais. Acta Botanica Brasilica 19: 493-500.

Mendes-Rodrigues C, Carmo-Oliveira R, Talavera S, Artista M, Ortiz PL Oliveira PE. 2005. Polyembriony and apomixis in Eriotheca pubescens (Malvaceae-Bombacoideae). Plant Biology 7: 533-540.

Ojeda F, Brun FG, Vergara JJ. 2005. Fire, rain and the selection of seeder and resprouter life-histories in fire-recruiting, woody plants. New Phytologist 168: 155-165.

Oliveira PE, Gibbs PE, Barbosa AA, Talavera S. 1992. Contrasting breeding systems in two Eriotheca (Bombacaeae) species of the Brazilian Cerrados. Plant Systematics and Evolution 179: 207-219.

Oliveira PE, Moreira AG. 1992. Anemocoria em espécies de cerrado e mata de galeria de Brasília, DF. Revista Brasileira de Botânica 15: 163-174.

Paiva AO, Silva LCR, Haridasan M. 2015. Productivity-efficiency tradeoffs in tropical gallery forest-savanna transitions: linking plant and soil processes through litter input and composition. Plant Ecology 216: 775-787.

Pausas JG. 2015. Bark thickness and fire regime. Functional Ecology 29: 315-327.

Raunkiaer C. 1934. The life forms of plants and statistical plant geography. Oxford, The Clarendon Press.

Raw A, Hay J. 1985. Fire and other factors affecting a population of Simarouba amara in cerradão near Brasília, Brazil. Revista Brasileira de Botânica 8: 101-107.

R Core Team. 2013. R: A language and environment for statistical computing. R Foundation for Statistical Computing, Vienna, Austria. URL http://www.R-project.org/.

Ribeiro ML. 2011. Reserva ecológica do IBGE: biodiversidade terrestre. Vol 1. Tomo 1. Rio de Janeiro, Coordenação de Recursos Naturais e Estudos Ambientais

Ribeiro MN, Sanchez M, Pedroni F, Peixoto KS. 2012. Fogo e dinâmica da comunidade lenhosa em cerrado sentido restrito, Barra do Garças, Mato Grosso. Acta Botanica Brasilica 26: 203-217.

Salomão AN, Leite AMC. 1993. Comportamento de regenerantes de Astronium urundeuva (Fr. All.) Engler em área sob ação antrópica. Acta Botanica Brasilica 6: 85-96.

Sato MN, Miranda HS, Maia JMF. 2010. O fogo e o estrato arbóreo do Cerrado: efeitos imediatos e de longo prazo. In: Miranda HS. (ed.) Efeitos do regime de fogo sobre a estrutura de comunidades de cerrado: projeto de fogo. Brasília, Ibama. p. 77-91.

Schafer JL, Breslow BP, Hollingsworth SN, Hohmann MG, Hoffmann WA. 2014. Size-dependent enhancement of water relations during post-fire resprouting. Tree Physiology 34: 404-414.

Silva IA, Batalha MA. 2009. Co-occurrence of tree species at fine spatial scale in a woodland cerrado, southeastern Brazil. Plant Ecology 200: 277-286.

Silva IA, Valenti MW, Silva-Matos DM. 2009. Fire effects on the population structure of Zanthoxylum rhoifolium Lam (Rutaceae) in a Brazilian savana. Brazilian Journal of Biology 69: 813-818.

Simon MF, Grether R, Queiroz LP, Skema C, Pennington RT, Hughes CE. 2009. Recent assembly of the cerrado, a neotropical plant diversity hotspot, by in situ evolution of adaptations to fire. Proceedings of the National Academy of Science 106: 20359-20364.

Simon MF, Pennington T. 2012. Evidence for adaptation to fire regimes in the tropical savannas of the brazilian cerrado. International Journal of Plant Sciences 173: 711-723.

Tredici P. 2001. Sprouting in temperate trees: a morphological and ecological review. Botanical Review 67: 121-140. 
How does resprouting response differ among three species of savanna trees and in relation to plant size?

Vale VS, Lopes SF. 2010. Efeitos do fogo na estrutura populacional de quatro espécies de plantas do cerrado. Revista Nordestina de Biologia 19: 45-53.

Vieira EM, Andrade I, Price PW. 1996. Fire effects on a Palicourea rigida (Rubiaceae) gall midge: a test of the plant vigor hypothesis. Biotropica 28: 210-217.
Vila M, Terradas J. 1995. Effects of competition and disturbance on the resprouting performance of the mediterranean shrub Erica multiflora L. (Ericaceae). American Journal of Botany 82: 1241-1248. 